\title{
SOIL MOISTURE SPACE-TIME ANALYSIS TO SUPPORT IMPROVED CROP MANAGEMENT
}

\author{
Análise espaço-temporal da umidade do solo como apoio \\ para melhoria do manejo da cultura
}

\author{
Bruno Montoani Silva ${ }^{1}$, Walbert Junior Reis dos Santos ${ }^{2}$, Geraldo César de Oliveira ${ }^{3}$, \\ José Maria de Lima ${ }^{3}$, Nilton Curi ${ }^{3}$, João José Marques ${ }^{3}$
}

\begin{abstract}
The knowledge of the water content in the soil profile is essential for an efficient management of crop growth and development. This work aimed to use geostatistical techniques in a spatio-temporal study of soil moisture in an Oxisol in order to provide that information for improved crop management. Data were collected in a coffee crop area at São Roque de Minas, in the upper São Francisco River basin, MG state, Brazil. The soil moisture was measured with a multi-sensor capacitance (MCP) probe at 10-, 20-, 30-, 40-, 60- and 100-cm depths between March and December, 2010. After adjusting the spherical semivariogram model using ordinary least squares, best model, the values were interpolated by kriging in order to have a continuous surface relating depth x time (CSDT) and the soil water availability to plant (SWAP). The results allowed additional insight on the dynamics of soil water and its availability to plant, and pointed to the effects of climate on the soil water content. These results also allowed identifying when and where there was greater water consumption by the plants, and the soil layers where water was available and potentially explored by the plant root system.
\end{abstract}

Index terms: Water use efficiency, soil management, deep soil tillage, plant-available water, arabica coffee.

\section{RESUMO}

O conhecimento do conteúdo de água no perfil do solo é essencial para um manejo eficiente das culturas. Objetivou-se, neste trabalho,utilizar técnicas de geoestatística no estudo espaço-temporal da água em um Latossolo Vermelho. Os dados foram coletados em área de cafeicultura no município de São Roque de Minas, na região Alto São Francisco, MG. O conteúdo de água no solo foi obtidopor meio de uma sonda com multissensores de capacitância (MCP) nas profundidades de $10 \mathrm{~cm}, 20 \mathrm{~cm}, 30 \mathrm{~cm}, 40 \mathrm{~cm}, 60 \mathrm{~cm}$ e $100 \mathrm{~cm}$, entre março a dezembro de 2010. Após o ajuste do semivariograma no modelo esférico, utilizando mínimos quadrados ordinários, melhor modelo,interpolaram-se os valores por meio de krigagem, gerando uma superfície contínua, profundidade versus tempo (SCPT) e superfície de disponibilidade de água para a planta (SDAP). Os resultados permitiram um entendimento adicional da dinâmica da água armazenada no solo e sua disponibilidade para a planta, mostrando os efeitos do clima na variação do conteúdo de água e também, principalmente, dos períodos e camadas, onde houve maior consumo hídrico pela planta e regiões onde há água disponível no solo, potencialmente explorável pelo sistema radicular.

Termos para indexação: Eficiência de uso da água, manejo do solo, preparo profundo do solo, disponibilidade de água para a planta, café arábica.

\section{INTRODUCTION}

Water holding capacity of soils is due to adsorption and capillary forces, that are an expression of soil structure and electrical charges, which can be changed according to soil management (Ferreira, Fernandes; Curi,1999; Oliveira, 2004; Tormena, Silva; Libardi,1999; Silva et al., 2012a; Veiga, Reinert; Reichert, 2010; Leão et al., 2006; Bamberg et al., 2011). The amount of stored water in a given soil is a result of rate of rainfall, irrigation, drainage, run-off and evapotranspiration (Silva et al., 2001; Mota et al., 2010); which all change seasonally within the soil profile.
These changes can be characterized using geoestatistical techniques that allow one to know the spatial distribution of soil moisture (Western et al., 2004). This soil moisture distribution is also time dependent (Grego et al., 2006; Herbst; Diekkrüger2003; Hu et al.,2010; Reichert et al., 2008; Reichardt et al., 2001; Vinnikov et al., 1996; Mello et al., 2011). Due to the highly intrinsic variability of moisture within the soil profile, time-space variation cannot be simultaneously plotted. However, based on geostatistical theory, there is no restriction to work with space and time simultaneously.

Chemical limitations are the main constraints for root growing in the soils from the Cerrado region in Brazil

\footnotetext{
${ }^{1}$ Universidade Federal de Lavras/UFLA - Departamento de Ciência do Solo/DCS - Cx. P. 3037 - 37200-000 - Lavras - MG - Brasil - montoani@gmail.com ${ }^{2}$ Instituto Federal de Ciência, Educação e Tecnologia do Sul de Minas Gerais/IFSULDEMINAS - Muzambinho - MG - Brasil

3Universidade Federal de Lavras/UFLA - Departamento de Ciência do Solo/DCS - Lavras - MG - Brasil

Received in august 24, 2014 and approved in september 8, 2014
} 
(Raij, 2008). Shallow and not optimally distributed root systems decrease the potential for water uptake by plants which is even worse during the dry season (from May to September) or even during short-term droughts during the rainy season, especially for a coffee crop (Evangelista, Carvalho; Sediyama, 2002). During recent years, the coffee crop is being expanded into the Cerrado region of Brazil, and farmers are mitigating the effects of water deficit with irrigation, because drought is the major environmental stress and may reduce coffee productivity up to $80 \%$ (DaMatta; Ramalho, 2006).

Some farmers from the Upper São Francisco River basin, which is included in the Cerrado region, have achieved high productivity in non-irrigated coffee crops, using a set of adequate management practices. These practices allow the root system to grow deeper in the soil and increase water uptake, particularly in Oxisols (Serafim et al., 2011). In view of these activities and, since water sources for irrigation are scarce (Ana, 2011), such strategies aiming at the optimization of water use in agricultural systems, including improved uptake of deeply stored soil water, justifies this study.

Increasing the understanding ofthe behavior of the soil water content in the profile over time will benefit producers. This work uses geostatistical techniques to create a continuous record ofsurface water content with depth and time (CSDT), allowing identifying soil depth and time-related water content in the soil. Thus, information on water deficit for crops, water table recharge, soil zones of greaterwater consumption by plants, moisture in the soil profile, and the effectiveness of water uptake by plants (especially during low rainfall) can be more easily attainable. There are two hypotheses involved: (1) there is water available deeper in the soil profile that can mitigate water stress; and (2) improving soil fertility deeper in the soil induces root expansion and, consequently, increases water uptake.

\section{MATERIAL AND METHODS}

\section{Experimental area characterization}

This study was carried out in an experimental area with a two-year old Coffea arabica L. Catucaí cultivar, spaced by $2.5 \times 0.65 \mathrm{~m}$ among plants. This experimental area is located at São Roque de Minas, Upper São Francisco River basin, Minas Gerais state, Brazil. The corresponding geographical coordinates are $20^{\circ} 15^{\prime}$ $\mathrm{S}$ and $46^{\circ} 22^{\prime} \mathrm{W}$ Greenwich. The climate is Cwa (humid subtropical climate), according to Köppen's classification system, with an average annual rainfall of 1,344 $\mathrm{mm}$ and a well-defined dry season (from May to September). The average annual temperature is $20.7^{\circ} \mathrm{C}$, the average relative humidity is $60 \%$ and the altitude is $900 \mathrm{~m}$ above the sea level (Menegasse, Gonçalves; Fantinel, 2002).

The soil is classified as dystrophic Red Latosol (Embrapa, 2013) or Haplustox (Soil Survey Staff, 1999). It is located at the summit of the landscape, in a gentle undulated relief (3-8 \% slope). Some soil characterization data are shown in table 1 . The management system includes a deep planting furrow $(0.50 \mathrm{~m}$ wide and 0.60 $\mathrm{m}$ depth), application of amendments and fertilizers, and incorportationfor homogenizing the fertility correction withdepth. More details about this management system can be obtained in Serafim et al. (2011).

Table 1 - Particle size distribution, bulk density and water retention at 0-100 $\mathrm{cm}$ depth of the studied soil.

\begin{tabular}{|c|c|c|c|c|c|c|}
\hline \multicolumn{3}{|c|}{$\begin{array}{l}\text { Particle size } \\
\text { distribution }\end{array}$} & \multicolumn{4}{|c|}{ Water retention } \\
\hline Clay & Silt & Sand & $\mathrm{D}_{\mathrm{b}}$ & FC & PWP & SAW \\
\hline -------" & $\mathrm{g} \mathrm{kg}^{-1}$ & ----- & $\mathrm{g} \mathrm{cm}^{-3}$ & ------ & $m^{3} m^{-3}$ & -------- \\
\hline 791 & 173 & 36 & 0,84 & 0.43 & 0.24 & 0.19 \\
\hline \multicolumn{7}{|c|}{$\begin{array}{l}\mathrm{B}_{\mathrm{d}} \text { - Bulk density, by volumetric ring method, obtained from Silva } \\
\text { et al. (2012a); FC - Field capacity, obtained by equilibrium of } \\
\text { undisturbed samples in suction unity at }-6 \mathrm{kPa} \text { potential (Mello } \\
\text { et al., 2002); PWP - Permanent wilting point, determined in } \\
\text { Richards chamber at -1500 kPa potential; SAW: Soil available } \\
\text { water capacity (FC - PWP). }\end{array}$} \\
\hline
\end{tabular}

\section{Soil moisture and rainfall monitoring}

Rainfall was monitored by a pluviometer installed at the experimental area. The soil water content was measured with a multi-sensor capacitance probe (MCP) (Profile probe-Delta T, Cambridge, UK). Because it is not a destructive method, the monitoring was done in the same place and at 10-, 20-, 30-, 40-, 60- and 100-cm depths. This probe was previously calibrated to the specific soil conditions under this study (Silva et al., 2012b). The probe was installed in the crop row between two coffee plants. The readings were taken daily during 276 days, throughout the 2010 dry season. A data logger was set up to register the volumetric water content at four-hour intervals $(0 \mathrm{~h} 00$; $04 \mathrm{~h} 00 ; 08 \mathrm{~h} 00 ; 12 \mathrm{~h} 00 ; 16 \mathrm{~h} 00$; and 20h00), in order to have a daily average.

\section{Continuous surface depth-time generation}

The space-time dependence of the volumetric water content in the soil was evaluated with a semivariogram 
developed using the software Surfer 9.0, according to equation 1:

$$
\hat{y}(h)=\frac{1}{2 N(h)} \sum_{i=1}^{N(h)}\left[Z\left(x_{i}\right)-Z\left(x_{i}+h\right)\right]^{2}
$$

Where: $N(h)$ is the number of pairs of experimental observations $\mathrm{Z}$ (xi) and $\mathrm{Z}(\mathrm{xi}+\mathrm{h})$, which are separated by $\mathrm{h}$ distance.

The semivariogram is represented by the $\gamma$ (h) versus $\mathrm{h}$ graphics. Through this graphic, it was adjusted using a spherical function, where the following parameters were determined: nugget effect $(\mathrm{C} 0)$, sill $(\mathrm{C} 0+\mathrm{C} 1)$ and range $(\mathrm{r})$. The degree of space-temporal dependency (DD) was calculated according to Vieira (2000). Due to the quadratic behavior of volumetric soil water content, for both soil depth and time, the trend of the data was modeled through the function $\mathrm{Z} 1=\mathrm{Z}-\left[\mathrm{AX}^{2}+\mathrm{BY}^{2}+\mathrm{CXY}+\mathrm{DX}+\mathrm{EY}+\mathrm{F}\right]$, where $\mathrm{Z} 1$ is the water content after modeling, $\mathrm{z}$ is the actual water content, $\mathrm{x}$ is the time variable, $\mathrm{y}$ is the depth variable, and $\mathrm{A}, \mathrm{B}, \mathrm{C}, \mathrm{D}, \mathrm{E}$ and $\mathrm{F}$ are the coefficients of adjustment of the model.

Kriging was the estimator used in this study to create the CSDT (Vieira, 2000). The surface response was generated in Surfer 9.0 and imported into a geographic information system considering the following water content classes: $<5,5-10,10-15$, 15-20, 20-25, 25-30, 30-35, 35-40, 40-45, 45-50, and $>50$ ( $\%$ in volume). These classes were used in order to show the temporal variation (during the study period), and spatiallyin the soil profile in order to identify periods and depths of water deficit, greater water consumption by coffee plants and water storage in the soil.

From the CSDT a map of soil water availability to plants (SWAP) was generated; the soil water contents were classified into easily drainable water ( $>43 \%$ by volume), plant available water (between 43 and $24 \%$ in volume), and strongly retained water $(<24 \%$ in volume). The limits of these classes were assigned according to the boundary values of water availability to plants (Table 1), according to the classical concept of plant available water capacity, proposed by Veihmeyer and Hendrickson (1949), which considers the soil moisture between field capacity and permanent wilting point as being available to plants (Kirkham, 2005; Reichardt; Timm, 2012). Despite its limitations, this concept is useful because it is based only on soil parameters, disregarding the complexity of the soilplant-atmosphere relationships. Statiscal analysis were performed in order to help the data interpretation, through accuracy test of CSDT and field observed data, using the root mean squared error (RMSE) and the coefficient of determination $\left(\mathrm{R}^{2}\right)$.

\section{RESULTS AND DISCUSSION}

The parameters of the adjusted semivariogram (Figure 1) are shown in table 2. The space-time dependence was strong, since the degree of dependence was lower than $25 \%$ (Cambardella et al., 1994).

By cross-validating the data (Figure 2), after kriging, a very strong relationship was observed between observed and predicted(coefficient of determination $=98 \%$ ), confirming the strong spacetime dependence of the soil moisture. The RMSE of $1.27 \%$ of volumetric water content also indicates a high accuracy.

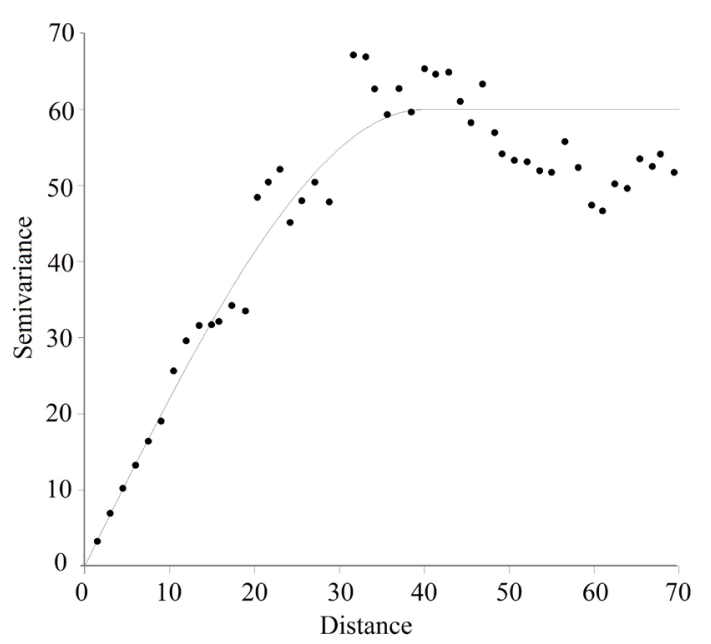

Figure 1-Semivariogram adjusted to the spherical model.

Table 2 - Semivariogram model parameters forsoil watercontent.

\begin{tabular}{lccccc}
\hline Model & $\mathrm{r}$ & $\mathrm{C}_{0}+\mathrm{C}_{1}$ & $\mathrm{C}_{0}$ & $\mathrm{DD}$ & $\begin{array}{c}\text { DD } \\
\text { Class }\end{array}$ \\
\hline & $\left(\mathrm{cm}^{2}+\mathrm{day}^{2}\right)^{1 / 2}$ & & $(\%)$ \\
\hline Spherical* & 38 & 62 & 0.1 & 0.16 & Strong \\
\hline $\begin{array}{l}\text { r-Range values; } \mathrm{C}_{0}+\mathrm{C}_{1} \text { - sill; } \mathrm{C}_{0} \text { - nugget effect; DD -dependency } \\
\text { degree; DD Class -class ofdependency degree. }\end{array}$ \\
$\begin{array}{l}\text { Akakie Information Corrected Criteria (AICc). } \\
\text { Akodel by }\end{array}$
\end{tabular}




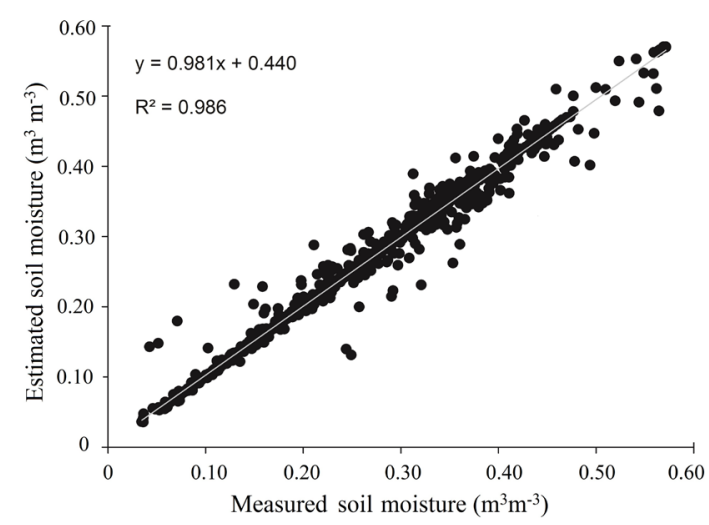

Figure 2 - Measured versus estimated values, crossvalidation of krigging.

The rainfall distribution during the studied period is presented on figure 3. A map of volumetric water content at different depths over time (CSDT) is shown on figure 4, and the map of soil water availability to the plants (SWAP) is presented on figure 5. These maps show that water content stored in the soil was highly correlated to the amount and distribution of rainfall (Figure 3).

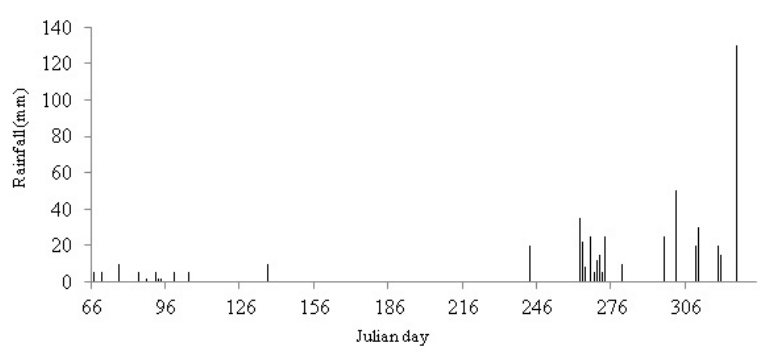

Figure 3 - Rainfall distribution during the studied period.

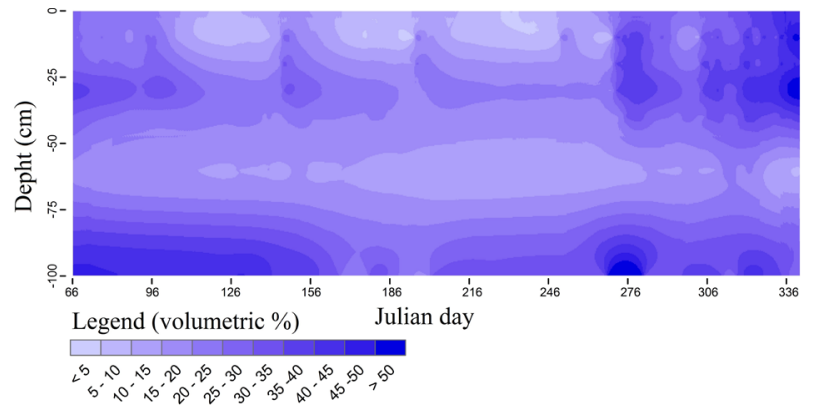

Figure 4 - Continuous surface depth $\mathrm{x}$ time (CSDT), of soil volumetric water content (volumetric \%) (March 07, 2010 to December 02, 2010).

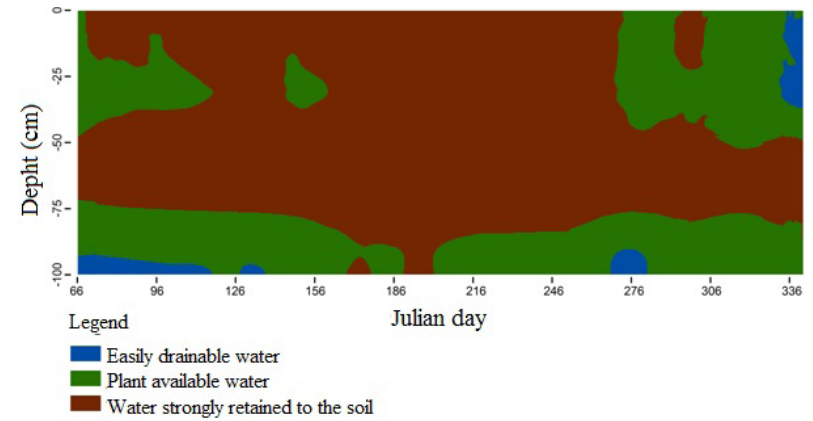

Figure 5 - Relationof soil water availability to the plant (SWAP) (March 07, 2010 to December 02, 2010).

The rainfall during the study period totaled 772 $\mathrm{mm}$. As for the distribution of rainfall, the longest drought period was 113 days, between days 137 (May 17) and 250 (September 07).

The rainfall event on day 250 increased the stored water content in the surface layers (Figure 4). After the day 270 (September 27), there was rainfall almost every day, characterizing the beginning of the rainy season. During this period the soil moisture in the whole soil profile was replenished (Figure 4). Particularly at the $0-50 \mathrm{~cm}$ layer, it is clear that the water content reached levels above the permanent wilting point, indicating the occurrence of water available to the plants (Figure 5). The moistening front at $85-100 \mathrm{~cm}$ depth, between days 270 and 285 (Figures 4 and 5), can also be attributed to the rainfall after day 270 .

During the period between days 146 (May 26) and 270 (September 27), considered as the dry season (Figure $3)$, there was a reduction in the amount of stored water in the soil (Figure 4). As a consequence, there was lesser availability of soil water to plants (Figure 5) from the soil surface up to $75-\mathrm{cm}$ depth. However, in some days within this period, the water was strongly retained in the soil, up to $100-\mathrm{cm}$ depth, as shown through the SWAP results.

Water contents below $10 \%$ were found only near the soil surface (15-cm layer), between days 115 (April 25) and 140 (May 20); between days 167 (June 16) and 195 (July 14); and between days 210 (July 29) and 249 (September 06). This happened because the topsoil is known to be more susceptible to lose water by evaporation due to the solar radiation and wind nearthe soil surface. On the other hand, precipitation also causes considerable variation of water storage in this layer $\mathrm{Hu}$ et al., 2010), that can be extended up to 30-cm depth (Figure 4). This constant change of water content near the soil surface may also due to water uptake by the roots (Mota et al., 2010). 
However, during the period from days 130 (July 14) and 147 (July 31), the volumetric water content of the soil surface ranged between 10 and $15 \%$, with no water supply by precipitation (Figure 3 ). As capillarity can move water in all directions in the soil, in other words, as water moves from a state of higher to lower matric potential (Reichardt;Timm, 2012), water content can also be increased by lateral or vertical flows. Red Latossols (Ustox), like the one of this experiment, have very good internal drainage, because of its granular structure, favored by the gibbsitic mineralogy (Ajayi et al, 2009; Ferreira, Fernandes; Curi,1999), confirmed by high amount of macropores $(>50 \mu \mathrm{m}$ diameter) (Silva et al., 2012a), and the slope is less than $8 \%$ (summit position), so the vertical flow largely predominates over horizontal flow (Reichardt;Timm, 2012). Beyond that, these soils are extremely homogeneous in morphology and do not present physical impedance to the vertical water flow (Oliveira et al., 2004).

In the 20-30- $\mathrm{cm}$ layer there were greater water contents compared to the surface layer and the layers close to $80 \mathrm{~cm}$ depth (Figure 4). This is due to the crop management system, since at that layer $(20-30 \mathrm{~cm})$ we observed in the field a 3-cm layer of gypsum, which was accumulated and not dissolved. This suggests that amending the soil with gypsum may be interfering on the water retention in this soil. This soil layer undergoes less influence of solar radiation, which contributes to higher water conservation. Another possibility is the soil microporosity at 5-, 20- and 40-cm depths, which is greaterthan that at 60- and 80-cm depths (Assis et al., 2011; Leão et al., 2006; Silva et al., 2011; Silva et al., 2012a; Veiga et al., 2010). This microporosity is accounting for a higher content of stored water (Figure 4), which is available to the plants, observed between days 66 and 116 , and between days 145 and 161 (Figure 5).

By observing the CSDT, there is an increasing gradient of water content below 55 -cm depth as compared to the upper layers, due to the water consumption by evapotranspiration. This is corroborated by Carlesso (1995), which describes that the depth of water consumption by roots can be characterized by an advancing front of water extraction in the soil profile as a function of time, with approximately the same rate of development of the root system. Water extraction through this front increased from the beginning of CSDT (day 66) until the beginning of the rainy season in September (day 250), being greater between days 160 and 240 (May-September), which represents the driest period in the studied region.

The interruption of this front of water extraction, after day 255 (Figures 4 and 5) may be associated to the soil remoistening, since it represents the beginning of the rainy season and the consequent increment of the soil available water to the plants in the 0 to $45-\mathrm{cm}$ and 75 to $100-\mathrm{cm}$ layers. According to Carlesso (1995), the delay of the front of water extraction is a function of the balance between soil water availability and evaporative demand. Thus, it occurs in soils with high quantity of water within the availability range.

By the CSDT and SWAP, the lower water content was in the 45 to $75-\mathrm{cm}$ layer, during the entire period of the experiment. It can be inferred that at this soil depth there was greater water uptake by the coffee root system under these studied conditions (age of plants, genetic material and soil management system adopted). It must be mentioned that the bottom of the furrow which was prepared for planting was at $60 \mathrm{~cm}$ depth, and that the whole soil material in this furrow was adequately amended with amendmentsand fertilizers. Since root system grows in layers where there are higher levels of nutrients and under adequate physical-hydric conditions (Brito, Libardi; Ghiberto,2009; Drew, 1975;Raij, 2008), it is suggested that in this layer (45-75 cm, Figure 5) the lesserwater content was due to the greater activity of the roots, extracting most of water neededby the coffee plant. Additionally, a large volume of roots is observed in this depth (Figure 6).

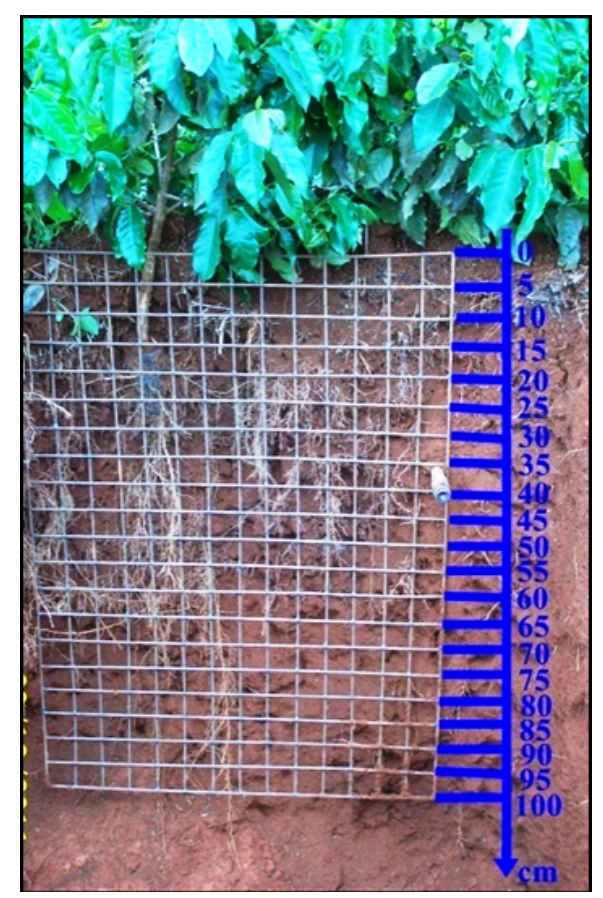

Figure 6 - View of the coffee root system in a pit, at the end of the first year after planting (December 08, 2009), before the moisture evaluations. 
The quantity of roots of Coffea Arabica changes widely in the soil profile as a response to the climatic changes. These changes are associated with root growth, which is seasonal and usually precedes the beginning of the aerial part growth (DaMatta et al., 2007). In Kenya, after a long drought period, the major activity of coffee roots was observed between 45 and $75 \mathrm{~cm}$ depth (Huxley et al., 1974). Daker (1976) proposed that the 60 to $80-\mathrm{cm}$ layer was the most favorable for coffee roots to uptake water, thus confirming the depth of lower water content observed by the CSDT. The plants in this study had not yet reached the adult phase (4-5 years), indicating a great root growth and subsequent displacement of the front of water extraction directed towards the deeper layers of the soil.

It is also noteworthy that the water content was above $30 \%$, mainly in the 80 to $100-\mathrm{cm}$ layer, between days 66 (March 07) and 167 (June 16), and between days 200 (July 19) and 301 (October 28) (Figure 4). This happens in deep and well drained soils, where water is drained to deeper layers during the rainy season, which is sometimes considered as a loss of water from the agricultural standpoint, although it is important from the environmental standpoint, for promoting groundwater recharge and supplying water sources. However, even deeper in the soil (Figure 5), the water may be taken upby plants, depending if the adopted soil management stimulates root to also grow deeper into the soil. Several studies have shown that deep roots are equally, or even more, efficient than the surface ones in absorbing water and nutrients (McCulley et al., 2004; Wiersum, 1967).

A short-term drought period was observed between October and November (days 290 to 306), which dried the soil tothe 0 to $25 \mathrm{~cm}$ depth. In other words, up to the depth of $25 \mathrm{~cm}$, the soil water content reached the permanent wilting point, which was severely affected by absence of rains between days 287 and 304 . This shows the importance of deeper root growth on promoting exploration of water in the soil profile.

As the depth from where water is extracted is preponderance over the potential quantity extractable per unit of depth, in the context of soil capacity to provide water to plants, deep rooted systems can improve yield of crops whichare exposed to water deficit conditions, by maintaining photosynthesis and transpiration flux with greater absorption of nutrients (Carlesso, 1995; DaMatta;Ramalho, 2006).

In the same region of this study, also in oxisol, Serafim et al. (2013) reported a common presence of very fine and fine roots in the 1.5 to $1.7 \mathrm{~m}$ layer, explained by the type of management practices. These were the same used in our study, which contributed to the greater root penetration. They also concluded that the deep furrow preparation, associated with gypsum amendment to remove toxicity, allowed the root system to explore a greater volume of soil. Based on this information, and considering the observations of Wiersum (1967) that the roots that are located at deeper layers in the soil have higher absorbing capacity of water and nutrients, it is suggested that there is a significant water extraction from deeper layers in this soil (Figures 4 and 5). This fact contributed to reduced hydric stress caused by the long term drought period and the short-term drought periods during the rainy season, as previously reported, with favorable effects on crop yield.

\section{CONCLUSIONS}

There was a considerable space-time and depth dependence of the soil volumetric water content, as evidenced by the DD and the semivariogram maps.

The CSDT generated by kriging showed high accuracy with alow RMSE and a high $\mathrm{R}^{2}$.

The CSDT allowed additional insight on the influence of rainfall, water extraction and redistribution of water in the space-temporal dynamics of soil water content stored in the soil profile. In order to improve the accuracy of information obtained by the CSDP, we suggest future studies employing other concepts to estimate the plant available water, such as least limiting water range - LLWR (Silva,Kay; Perfect, 1994) or integral water capacity (Asgarzadeh et al., 2011; Minasny; Mcbratney, 2002) instead of soil plant available water (Veihmeyer; Hendrickson, 1949) approach.

The surface layer of soil had the greatest variability in the soil water content.

The 50 to $75-\mathrm{cm}$ layer showed the least water content throughout the studied period, indicating an increased activity of the coffee root system in absorbing water in this layer.

By the SWAP measurements it may be inferred that below the $80-\mathrm{cm}$ depth there was water available to the plants throughout the study period.

\section{ACKNOWLEDGEMENTS}

The authors thank CNPq for the scholarship granted to the first author; Embrapa Café and FAPEMIG for funding the project; and EPAMIG and AP Group for the logistical support and assistance on the field work. The authors also thank Dr. Paulo Gontijo Guimarães/ EPAMIG and Dr. Marcelo Silva Oliveira/UFLA-DEX for technical support. 


\section{REFERENCES}

AJAYI, A. E. et al. Relation of strength and mineralogical attributes in Brazilian latosols. Soiland Tillage Research. (102):14-18, 2009.

ANA. Agencia Nacional de Águas - Conjuntura dos Recursos Hídricos no Brasil. Available in $<\mathrm{http}$ :// conjuntura.ana.gov.br/conjuntura/abr_nacional.htm>. Accessed on Feb. 17th, 2012.

ASGARZADEH, H. et al. Integral energy of conventional available water, least limiting water range and integral water capacity for better characterization of water availability and soil physical quality. Geoderma. (166):34-42, 2011.

ASSIS, A. C. C. et al. Water availability determines physiognomic gradient in an area of low-fertility soils under Cerrado vegetation. Plant Ecology. (212):1135-1147, 2011.

BAMBERG, A. L. et al. Temporal changes of soil physical and hydraulic properties in strawberry fields. Soil Use and Management. (27):385-394, 2011.

BRITO, A. dos S.; LIBARDI, P. L.; GHIBERTO, P. J. Componentes do balanço de água no solo com canade-açúcar, com e sem adubação nitrogenada. Revista Brasileira de Ciência do Solo. (33):295-303, 2009.

CAMBARDELLA, C. A. et al. Field scale variability of soil properties in central Iowa soil. Soil Science Society of America Journal. (47):1501-1511, 1994.

CARLESSO, R. Absorção de água pelas plantas: água disponível versus extraível e a produtividade das culturas. Ciência Rural. (25):183-188, 1995.

DAKER, A. A água na agricultura: Manual de hidráulica agrícola. 5 ed. Rio de Janeiro: Freitas Bastos, 1976, 453p.

DAMATTA, F. M. et al. Ecophysiology of coffee growth and production. Brazilian Journal of Plant Physiology. (19):485-510, 2007.

DAMATTA, F. M.; RAMALHO, J. D. C. Impacts of drought and temperature stress on coffee physiology and production: a review. Brazilian Journal of Plant Physiology. (18): 55-81, 2006.
DREW, M. C. Comparison of the effects of a localized supply of phosphate, nitrate, ammonium and potassium on the growth of the seminal root system, and the shoot, in barley. New Phytologist. (75):479-490, 1975.

EMBRAPA - EMPRESA BRASILEIRA DE PESQUISA AGROPECUÁRIA. Sistema Brasileiro de Classificação de Solos. 3.ed. Rio de Janeiro, 2013. $353 \mathrm{p}$.

EVANGELISTA, A. W. P.; CARVALHO, L. G. DE; SEDIYAMA, G. C. Zoneamento climático associado ao potencial produtivo da cultura do café no Estado de Minas Gerais. Revista Brasileira de Engenharia Agrícola e Ambiental. (6):445-452, 2002.

FERREIRA, M. M.; FERNANDES, B.; CURI, $\mathrm{N}$. Influência da mineralogia da fração argila nas propriedades físicas de Latossolos da região sudeste do Brasil. Revista Brasileira de Ciência do Solo.(23):515524, 1999.

GREGO, C. R. et al. Geostatistical analysis for soil moisture content under the no tillage cropping system. Scientia Agricola. (63):341-350, 2006.

HERBST, M.; DIEKKRÜGER, B. Modeling the spatial variability of soil moisture in a micro-scale catchment and comparison with field data using geostatistics. Physics and Chemistry of the Earth. (28):239-245, 2003.

HU, W. et al. Watershed scale temporal stability of soil water content. Geoderma. (158):181-198, 2010.

HUXLEY, P. A. et al. Tracer studies with $\mathrm{P}$ on the distribution of functional roots of Arabica coffee in Kenya. Annals of Applied Biology. (77):159-180, 1974.

KIRKHAM, M. B. Principles of soil and plant water relations. Amsterdan: Elsevier Academic Press, 2005. 500 p.

LEÃO, T. P. et al. Least limiting water range : A potential indicator of changes in near-surface soil physical quality after the conversion of Brazilian Savanna into pasture. Soil and Tillage Research. 88:279-285, 2006. 
McCULLEY, R. L. et al. Nutrient uptake as a contributing explanation for deep rooting in arid and semi-arid ecosystems. Oecologia. (141):620-628, 2004.

MELLO, C. R. et al. Estimativa da capacidade de campo baseada no ponto de inflexão da curva característica. Ciência e Agrotecnologia. (26):836-841, 2002.

. Spatial distribution of top soil water content in an experimental catchment of Southeast Brazil. Scientia Agricola. (68):285-294, 2011.

MENEGASSE, L. N.; GONÇALVES, J. M.; FANTINEL, L. M. Disponibilidades hídricas na Província cárstica de Arcos-Pains-Doresópolis, Alto São Francisco, Minas Gerais, Brasil. Revista Águas Subterrâneas. (16):9-21, 2002.

MINASNY, B.; MCBRATNEY, A. B. Integral energy as a measure of soil-water availability. Plant and Soil. (249):253-262, 2002.

MOTA, J. C. A. et al. Armazenagem de água e produtividade de meloeiro irrigado por gotejamento, com a superfície do solo coberta e desnuda. Revista Brasileira de Ciência do Solo. (34):1721-1731, 2010.

OLIVEIRA, G. C. et al. Caracterização química e físico-hídrica de um Latossolo Vermelho após vinte anos de manejo e cultivo do solo. Revista Brasileira de Ciência do Solo. (28):327-336, 2004.

RAIJ, B. V. Gesso na agricultura. Campinas: Instituto Agronômico, 2008. 233p.

REICHARDT, K. et al. Soil spatial variability and the estimation of the irrigation water depth. Scientia Agricola. (58):549-553, 2001.

REICHARDT, K.; TIMM, L.C. Solo, planta e atmosfera: conceitos, processos e aplicações. Barueri: Manole, 2012. 524p.

REICHERT, J.M. et al. Variabilidade espacial de Planossolo e produtividade de soja em várzea sistematizada: análise geoestatística e análise de regressão. Ciência Rural. (38):981-988, 2008.

SERAFIM, M. E. et al. Sistema conservacionista e de manejo intensivo do solo no cultivo de cafeeiros na região do Alto São Francisco, MG : um estudo de caso. Bioscience Journal. (27):964-977, 2011.

SERAFIM, M. E. et al. Disponibilidade hídrica e distinção de ambientes para cultivo de cafeeiros.

Revista Brasileira de Engenharia Agrícola e Ambiental. (17):362-370, 2013.

SILVA, A. P.; NADLER, A.; KAY, B. Factors contributing to temporal stability in spatial patterns of water content in the tillage zone. Soil and Tillage Research. (58):207-218, 2001.

SILVA, B. M. et al. Índice S no diagnóstico da qualidade estrutural de Latossolo muito argiloso sob manejo intensivo. Bioscience Journal. (28):338-345, 2012.

. Acurácia e calibração de sonda de capacitância em Latossolo Vermelho cultivado com cafeeiro. Pesquisa Agropecuária Brasileira. (47): $277-$ 286, 2012b.

SILVA, A. P.; KAY, B. D.; PERFECT, E. Characterization of the Least Limiting Water Range of soils. Soil Science Society of America Journal. (58): 1775-1781, 1994.

SILVA, G. L. et al. Soil physical quality of Luvisols under agroforestry, natural vegetation and conventional crop management systems in the Brazilian semi-arid region. Geoderma, (167-168):61-70, 2011.

\section{SOIL SURVEY STAFF. Soil Taxonomy, A Basic} System of Soil Classification for Making and Interpreting Soil Surveys. 2 ed. Washington: USDA Soil Conservation Service, US Gov. Printing Office, 1999. 869p.

TORMENA, C. A.; SILVA, A. P. da; LIBARDI, P. L. Soil physical quality of a Brazilian Oxisol under two tillage systems using the least limiting water range approach. Soil and Tillage Research. (52):223-232, 1999.

VEIGA, M.; REINERT, D. J.; REICHERT, J. M. Tillage systems and nutrient sources affecting soil cover, temperature and moisture in a clayey oxisol under corn. Revista Brasileira de Ciência do Solo. (34):20112020, 2010. 
VEIHMEYER, F. J.; HENDRICKSON, A. H. Methods of measuring field capacity and wilting percentages of soils. Soil Science. (68):75-94, 1949.

\section{VIEIRA, S. R. Geoestatística em estudos de} variabilidade espacial do solo. In: NOVAIS, R. F. et al. (Eds.). Tópicos em Ciência do Solo, 1. Sociedade Brasileira de Ciência do Solo, 2000. 1-53. p.

VINNIKOV, K. Y. et al. Scales of temporal and spatial variability of midlatitude soil moisture.
Journal of Geophysical Research. (101):7163-7174, 1996.

WESTERN, A. W. et al. Spatial correlation of soil moisture in small catchments and its relation ship to dominant spatial hydrological processes. Journal of Hydrology. (286):113-134, 2004.

WIERSUM, L. K. Potential subsoil utilization by roots. Plant and soil. (17):383-400, 1967. 